UDC 811.11-112

DOI: $10.17223 / 24109266 / 8 / 5$

\title{
LINGUOCULTUROLOGICAL FEATURES OF ANCIENT MYTHONYMS (BASED ON ENGLISH AND GERMAN LANGUAGES)
}

\author{
I.L. Kuchesheva \\ Siberian State University of Physical Education and Sport (Omsk, Russian Federation) \\ E-mail: kuchesheva@rambler.ru
}

\begin{abstract}
The article is devoted to linguocultorological analysis of ancient mythonyms to describe flora and fauna, space (based on English and German). Relevance of the study is specified by the fact that ancient mythonyms denoting insects, birds, plants, planets, chemical elements, constellations, mountains, animals, substances are insufficiently studied both in native and in foreign linguistics. The paper gives the definitions of such concepts as mythonym, cultural linguistics, general cultural lexicon. Methods of continuous sampling, etymological, semantic and linguoculturological analysis are used in the paper. The paper examines lexical units and gives their thematic classification such as: insects, birds, plants, planets, chemical elements, constellations, mountains, animals, substances taken from the ancient mythology from the position of cultural linguistics. The etymology and examples from English and German fiction are given for deeper understanding of ancient mythonyms. The author pays attention to the peculiarities of spelling mythonyms in English and German. The analysis revealed that the feature of ancient mythonyms in English and German is that they refer to general cultural lexicon because they are used in two or more languages.
\end{abstract}

Keywords: cultural linguistics; mythonym; ancient; general cultural lexicon; onomastics.

\section{Introduction}

The magical function of language in archaic cultures is due to mythological beliefs of the people and inspiration of the whole world. In the opinion of E. Cassirer, the structure of the mythological language of the world is largely determined by the same spiritual concepts: "The myth revives and enriches itself due to the language, and the language revives and enriches itself due to the myth" [1:41].

The relevance of the study is due to ancient mythonyms denoting insects, birds, plants, planets, chemical elements, constellations, mountains, animals, substances are insufficiently studied both in native and in foreign linguistics.

The lack of complete research of the semantic and etymological features of ancient mythonyms in English and German leads to some difficulties in translation of literature and through intercultural communication. 
The novelty of this research is its comprehensive study of ancient mythonyms in English and German carried out for the first time. Linguoculturological importance and functioning in speech and literature is shown in the paper.

Etymological analysis of ancient mythonyms in English and German from the perspective of cultural linguistics is carried out and thematic classification is given for the first time.

The main purpose of this paper is to identify the linguoculturological characteristics of ancient mythonyms in English and German and their functioning in literature through etymological analysis.

The practical significance of the study is that the results can be used in the preparation of the English-German onomastic dictionaries, in the preparation of courses, special courses and textbooks on lexicology.

Sixty-four English and German lexical units (ancient mythonyms) served as the material for the research and were selected by continuous sampling from English and German lexicographical sources, and English and German literature.

\section{Methodology}

Methods of continuous sampling, etymological, semantic and linguoculturological analysis are used in the paper.

The works of foreign and native authors serve the theoretical framework of the study:

- on onomastics: A. Gardiner (1954), A.V. Superanskaya (1973), N.V. Podolskaya (1990), L.A. Vvedenskaya (1989);

- on the cultural linguistics: V.V. Vorobyov (1997), V.A. Maslova (2001);

- on mythology: E.M. Meletinsky (1977), A.F. Losev (1982); G.M. Matveev (2003).

\section{Research}

Legends and myths describe a lot of things which have never existed in the world. But nowadays people do not have doubts about their reality. Many of them have remained up to the present time in English and German onomastics.

To investigate it the myth is available only in the form of figurative and verbal trace, while the live self-replicating myth is a special type of thinking chronologically and essentially opposed to historical and natural way of thinking [2: 19].

Views on the way people thought about the world were reflected in ancient myths, religions, epic works and tales. 
Onomastics (Greek "onomastike" - "Art to give names") - is a special branch of linguistics dealing with the study of proper names. Onomastics includes personal names, surnames, nicknames, names of towns, streets, squares, villages, hills, rivers, lakes, seas, celestial bodies.

Mythological onomastics as a set of proper names of supernatural beings is a significant part of onomastic space [3: 14].

Mythonyms are names of people, animals, plants, peoples, geographical and cosmographical objects, various things and so on, which in fact have never existed. Names in myths represent considerable interest for researchers of history of mankind. Grains of information about earlier stages of human history can be derived from mythonyms [4: 55].

Mythonyms which include proper names, taken from ancient (GrecoRoman) legends form national identity system and linguistic culture.

As for the definition of V.A. Maslova, "cultural linguistics is the science which appeared at the junction of linguistics and cultural studies and investigates cultural manifestations of people that reflected and consolidated in language" [5: 28].

V.V. Vorobyev considers that cultural linguistics is viewed as "a complex scientific discipline of synthesizing type, which studies the relationship and interaction between culture and language in its functioning and reflects the process as an integral structure of units in the unity of their linguistic and extra-linguistic (cultural) content using system methods and focusing on up-to-date priorities and cultural establishments (a system of norms and human values)" [6: 36-37].

It is of great importance to know the etymology of proper names taken from the ancient mythology. It is necessary to find out what historical information they contain and to learn meanings that are summarized in the structure of these lexical units.

Sixty-four English and German lexical units were selected for the analysis in the paper.

Thematic classification of ancient mythonyms in English and German defining insects, animals, birds, plants, mountains, substances, constellations, planets and chemical elements are analyzed and composed.

\section{Insects}

- eng. psyche - germ. Psyche - a beautiful butterfly (in Greek mythology the personification of the human soul, is named after the king's daughter Psyche. She was depicted in the image of a girl with butterfly wings).

E.g.: In der Hand die kleine Lampe, In der Brust die große Glut,

Schleichet Psyche zu dem Lager, Wo der holde Schläfer ruht.

Sie errötet und sie zittert, Wie sie seine Schönheit sieht

Der enthüllte Gott der Liebe, Er erwacht und er entflieht. 
Achtzehnhundertjähr'ge Buße! Und die Ärmste stirbt beinah!

Psyche fastet und kasteit sich, Weil sie Amorn nackend sah [7: 195].

- eng. galatea - germ. Galatea - a butterfly (a beautiful statue created by the sculptor Pygmalion and revived on his prayers by the goddess Aphrodite; shirt striped cotton fabric named after Galatea (in Greek mythology one of the daughters of the sea-god Nereus, personification of the quiet sea).

E.g.: Galatea never does quite like Pygmalion: his relation to her is too godlike to be altogether agreeable [8: 193].

- eng. hercules - germ. Herkules - a big beetle living in South America (named after the mythic Hercules, the strongest of Greek heroes).

\section{Birds}

- eng. harpy - germ. Harpyie - a big bird of prey; a genus of bats living in India, named after the Greek goddess of vortex and death Harpy [9].

E.g.:

Here the repellent harpies make their nests,

Who drove the Trojans from the Strophades

With dire announcements of the coming woe.

They have broad wings, a human neck and face,

Clawed feet and swollen, feathered bellies; they caw

Their lamentations in the eerie trees [10].

\section{Plants}

- eng. hyacinth - germ. Hyazinthe - a genus of perennial bulbous plants of the lilaceous family; red or reddish-brown transparent variety of mineral zircon, used as a gemstone (named after Greek youth Hyacinth).

E.g.: About them lay long launds of green grass dappled with celandine and anemones, white and blue, now folded for sleep; and they were acres populous with the leaves of woodland hyacinths: already their sleek bell-stems were thrusting through the mould [11:681].

- eng. andromeda - germ. Andromeda - evergreen bushes of the heath family (named after the daughter of the Ethiopian king Cepheus);

- eng. sequoia - germ. Sequoia - a genus of evergreen coniferous trees of the Taxodiaceae family (named after the leader of the Indian Cherokee tribe).

\section{Constellations}

- eng. Orion - germ. Orion - a constellation of vault of heaven (Orion in Greek mythology is the Boeotian giant hunter). 


\section{Mountains}

- eng. Volcano - germ. Vulkan - a fire-breathing mountain (named after the mythical Roman god of fire and blacksmith Vulcan).

Animals:

- eng. triton - germ. Triton - a genus of suborder of salamanders (named after the sea-god Triton).

\section{Substances}

- eng. myrrh - germ. Myrrhe - aromatic resin of some African and Arabian trees that freezes in the air and is used in medicine and perfume (named after the Greek woman Myrrh. Gods in Greek mythology turned her into the tree).

\section{Planets}

- eng. Venus - germ. Venus - one of nine major planets that is the closest to the Earth (named after the ancient Roman goddess of love and beauty Venus);

- eng. Mars - germ. Mars - a planet (named after the ancient Roman god of war Mars);

- eng. Jupiter - germ. Jupiter - the biggest and the brightest of nine planets of the solar system (named after the Roman supreme god of light, thunder and lightning Jupiter);

- eng. Mercury - germ. Merkur - a planet (named after the Roman god of trade Mercury);

- eng. Uranus - germ. Uran - a planet (named after the Greek god of the sky Uranus);

- eng. Neptune - germ. Neptun - a planet (named after the Roman lord of water Neptune (Greek Poseidon), whose symbol is the trident);

- eng. Pluto - germ. Pluto - a planet (named after the Roman god of the underworld kingdom Pluto);

- eng. Pallas - germ. Pallas - a planet (named after Pallas, the daughter of Triton and a friend of Athena);

- eng. Ceres - germ. Ceres - a planet (named after the ancient Greek goddess of agriculture and fertility Ceres).

English and German names of planets after ancient characters are written with the capital letter.

\section{Chemical elements}

- eng. neptunium - germ. Neptunium - a chemical element (named after the planet Neptune); 
- eng. niobium - germ. Niobium - a chemical element (named after Niobe, the daughter of mythological Tantalus);

- eng. palladium - germ. Palladium - a chemical element (named after the planet Pallas);

- eng. plutonium - germ. Plutonium - a chemical element (named after the planet Pluto);

- eng. promethium - germ. Promethium - a chemical element (named after Prometheus);

- eng. tantalum - germ. Tantalum - a chemical element (named after Tantalus, the hero of Greek mythology, in connection with difficulty of metal mining).

The analysis led to the conclusion that lexical units that include names of chemical elements and planets relate to general cultural lexicon.

General cultural lexicon has the same lexical meaning, the source language, functioning in two or more languages, but not always coinciding graphically and phonetically.

Names of chemical elements after ancient characters are written with the lowercase letter.

The peculiarity of the names of chemical elements such as neptunium, named after the planet Neptune (after the Roman sea god Neptune); palladium - named after the planet Pallas (after the Greek goddess Pallas), plutonium - named after the planet Pluto (after the Roman god of underworld kingdom Pluto), have double nomination.

\section{Conclusion}

The analysis reveals that ancient mythonyms designating planets and constellations in English and German are written with the lowercase letter. Mythonyms designating insects, birds, plants, mountains, animals and substances in English are written with a capital letter, while in German they are written with a lowercase letter.

The ancient mythonyms transferred to various items such as insects, birds, plants, planets, chemical elements, constellations, mountains, animals and substances belong to general cultural lexicon because they are found in two and more languages but have phonetic differences connected with the peculiarities of pronunciation of English and German.

To sum up, lexical units of mythological origin denoting insects, birds, plants, planets, chemical elements, constellations, mountains, animals, substances entered the lexicon of English and German as a result of human cognitive activity and received their names after mythical characters and ancient heroes. Myths are transferred orally from generation to generation and with the advent of writing started to be written on papyrus, paper. Ancient legends help scientists to get to the deep roots of the history of countries and peoples. 


\section{References}

1. Cassirer, E. (1990). The power of metaphor. The theory of metaphor. Moscow: Progress. $75 \mathrm{p}$.

2. Makovsky, M.M. (1996). Mythological symbolism in Indo-European languages: the image of the world and the worlds of images. Moscow: VLADOS. $416 \mathrm{p}$.

3. Plakhova, O.A. (2007). English fairy tales in ethnolinguistic aspect. Cand. Diss. Nizhny Novgorod. $221 \mathrm{p}$.

4. Kuchesheva, I.L. (2015). The analysis of mythonyms in German and English phraseological units. Foreign languages at school. 10. pp. 55-58.

5. Maslova, V.A. (2001). Cultural linguistics. Moscow: Academy. 208 p.

6. Vorobyev, V.V. (1997). Cultural linguistics (theory and methods). Moscow: Publishing House of the Russian. University of Peoples' Friendship. 331 p.

7. Heine, H. (2007). Neue Gedichte. Oxford: Hoffmann und Kampe. 343 p.

8. Shaw, G.B. (2005). Pegmalion. New York: Dover Publications. 194 p.

9. Harpy. Available from: https://en.wikipedia.org/wiki/Harpy (accessed: 01.09.2016).

10. Dante Alighieri. (1918). The Divine Comedy of Dante Alighieri. The Italian Text with a Translation in English Blank Verse and a Commentary by Courtney Langdon. 1 (Inferno) Cambridge: Harvard University Press. English version. Available from: http://oll.libertyfund.org/titles/2308\#Dante_0045-01_EN_40 (accessed: 13.06.2016).

11. Tolkien, J.R.R. (2012). The Lord of the Rings. The Two Towers. Boston, New York: Houghton Mifflin Harcourt. 715 p.

Resived 02.09.2016.

\section{Information about the author}

Kuchesheva Irina - Ph.D., Associate Professor, Department "Public Relations and Foreign Languages", Siberian State University of Physical Education and Sport (Omsk, Russian Federation). E-mail: kuchesheva@rambler.ru 